\title{
The Preparation and Performance of $\mathrm{WO}_{3} @ \mathrm{C}$ as a Counter Electrode Catalyst for Dye-Sensitized Solar Cell
}

\author{
Weizhen $C u i^{1,2}$, Jing $\mathrm{Ma}^{1}$,Kezhong $\mathrm{Wu}^{1, *}$, Jing Chen ${ }^{1}$, mingxing $\mathrm{Wu}^{1, *}$ \\ ${ }^{1}$ Department of Chemistry and Material Science, Hebei Normal University, Shijiazhuang 050024, \\ China \\ ${ }^{2}$ Department of Chemistry and chemical engineering, Cangzhou normal College, Hebei Cangzhou \\ 061001, China \\ *E-mail: wukzh688@163.com
}

doi: $10.20964 / 2017.12 .72$

Received: 5 May 2017 / Accepted: 20 September 2017 / Published: 12 November 2017

\begin{abstract}
Tungsten trioxide $\left(\mathrm{WO}_{3}\right)$ loaded on activated charcoal powder (ACP) was sprayed onto ITO conductive glass for using in dye-sensitized solar cells(DSSC). The results showed that the composite electrode of $\mathrm{WO}_{3} @ \mathrm{ACP}$ had apparently catalytic activity as a counter electrode for the regeneration of the traditional iodide / triiodide $\left(\mathrm{I}^{-} / \mathrm{I}^{3-}\right)$ redox pair. In the dye-sensitized solar cell, the power conversion efficiency on $\mathrm{WO}_{3} @ \mathrm{ACP}$ was $5.04 \%$, which was 3.15 times higher than $1.61 \%$ on the $\mathrm{WO}_{3}$. The followed were the electrical properties test of cyclic voltammetry $(\mathrm{CV})$, electrochemical impedance spectroscopy(EIS) and Tafel polarization curve. It was further explained that the catalytic activity of $\mathrm{WO}_{3} @ \mathrm{ACP}$ was obviously affected by the dispersion of $\mathrm{WO}_{3}$ particles on activated carbon powder.
\end{abstract}

Keywords: Tungsten trioxide; activatrd charcoal powder; Catalyst; Counter electrode; Solar cell

\section{FULL TEXT}

(C) 2017 The Authors. Published by ESG (www.electrochemsci.org). This article is an open access article distributed under the terms and conditions of the Creative Commons Attribution license (http://creativecommons.org/licenses/by/4.0/). 